the wooden shoes he wore as a child and his passion to keep good leather shoes on his children's feet was almost an obsession.

Came a black-bordered letter from Holland one day in 1888-Mynheer Mendens was dead; but his Betje occupied a decent place in American life.

My "simple annals of the poor" can be paralleled in thousands of mid-western families and homes. America -God bless her, and guide her that she may continue to promote the general welfare and secure the blessings of liberty to ourselves and our posterity.

\title{
GOVERNOR LUCAS FLAYED SINS .
}

By JACOB E. REIZENSTEIN

"Wets" and "Drys" have clashed in Iowa every year, every decade, and every generation throughout the last 107 years. Territorial Iowa split as to the advisability of "total abstinence," "moderate use," "use and abuse," "licensed saloons, inns, or taverns," and actual prohibition of the manufacture or sale of liquor, as far back as 1838.

The same thing is true, in a more limited measure, as to gambling. Such speculation was condemned, of course, by vastly more people than the number that attacked alcoholic beverages as "refreshments."

Nevertheless, when Iowa City was young dicing and card playing and other forms of gambling were highly popular amusements among many pioneers. Such pastimes were not limited to the "rag, tag, and bobtail" of the community, and the "scum of society." Some of the foremost citizens of the county indulged in games of chance.

They were even penalized by the early courts, as records in the faded and stained-yellow pages of court 
house books and files of a century and more ago reveal. Even officials of the county were tried, convicted, and fined for gambling.

One of the earliest antagonists of both liquor-drinking and games of chance was the territory's foremost citizen of 1838, His Excellency Robert Lucas, the first territorial governor of the new commonwealth carved out of Wisconsin territory and the Louisiana Purchase. He attacked them in his very first gubernatorial message, which he read to the Iowa legislature, in Burlington (the temporary seat of the Hawkeye government), which opened its first session on the second Monday of November, 1838, that is, the 12th day of the month. The governor lashed both of the weaknesses of man (and the genus homo is mentioned generically, rather than specifically, in this instance, although gambling and "drinking" were not indulged in by the "fair sex," of the 1830's, in the new territory, to any extent comparable with the gaming and cocktailing of the current era.) He progressively described the two famous (or infamous) pastimes, as "vices," "sins," and "crimes"-or, at any rate, as crimegenerators.

His address contained these scathing, almost vitrolic statements: "Most disastrous consequences proceed from practices that, in some places, are considered only 'fashionable vices'-namely, gambling and intemperance!"

Among his other declarations in the same message, we find: "These two vices may be considered the fountains from which almost every other crime proceeds, as penitentiaries conclusively show. They have produced more murders, robberies, and individual distress than all other crimes put together. This is evident, when we consider the many thousands that annually destroy themselves, and bring their families to beggary and wretchedness, by pursuing these vices. Surely there can be no murder of a deeper moral dye than self-murder; no robbery, more heinous than robbery of our own families."-Iowa City Press-Citizen. 
Copyright of Annals of Iowa is the property of State of Iowa, by \& through the State Historical Society of Iowa and its content may not be copied or emailed to multiple sites or posted to a listserv without the copyright holder's express written permission. However, users may print, download, or email articles for individual use. 